\title{
Loess and palaeosols on the High Terrace at Sierentz (France), and implications for the chronology of terrace formation in the Upper Rhine Graben
}

\author{
Philippe Rentzel ${ }^{1, *}$, Frank Preusser $^{2}$, Christine Pümpin ${ }^{1} \&$ Jean-Jacques Wolf ${ }^{3}$
}

Key words: High Terrace, loess, pedostratigraphy, micromorphology, luminescence dating, Upper Rhine Graben, Quaternary

\begin{abstract}
Pedological investigations in combination with luminescence dating have been used to reconstruct the genesis and chronology of a sediment succession at Sierentz, France. The sequence comprises loess and palaeosols on top of gravel attributed to the High Terrace of River Rhine. According to the dating results, three phases of soil development occurred during different warm phases of Marine Isotope Stage (MIS) 7 (245-190 ka). Soil development on top of the gravel occurred either during early MIS 7 or during an earlier warm phase, possibly MIS 9. The results imply a minimum age of $250 \mathrm{ka}$ for the formation of the High Terrace in this part of the Upper Rhine Graben, contrary to previous assumptions that correlated gravel sheet deposition with MIS 6 (ca. $150 \mathrm{ka}$ ). These results and recent findings at other sites suggest that the chronological setting of terrace formation north of the Alps is much more complex than previously assumed.
\end{abstract}

\section{ZUSAMMENFASSUNG}

Eine komplexe Deckschichtenabfolge aus Lössen und Paläoböden auf der Hochterrasse des Rheins bei Sierentz, Frankreich, wurde mittels bodenkundlicher Methoden und in Kombination mit Lumineszenzdatierungen untersucht, um die Schichtgenese zu rekonstruieren und Aussagen über das Alter der Abfolge zu erhalten. Nach den Datierungsergebnissen fallen drei Phasen von Bodenbildungen innerhalb der Hangfussablagerungen in das Marine Isotopen Stadium (MIS) 7 (245-190 ka). Die Bodenbildung im Top der fluvioglazialen Rheinschotter wird entweder dem frühesten MIS 7 oder einer älteren Warmphase, möglicherweise MIS 9, zugeordnet. Nach diesen Resultaten ergibt sich ein Minimalalter von 250 ka für Aufschotterung der Hochterrasse in diesem Teil des Oberrheingrabens, was im Gegensatz zu bisherigen Annahmen steht, die von einer Korrelation mit dem MIS 6 (ca. 150 ka) ausgingen. In Kombination mit Ergebnissen von anderen Stellen impliziert dies, dass die chronologische Situation der Terrassenbildung nördlich der Alpen anscheinend viel komplexer ist als bisher meist angenommen wurde.

\section{RÉSUMÉ}

Sur la base d'investigations pédostratigraphiques combinées à des datations par luminescence, il a été possible de reconstituer la genèse des sédiments - graviers, loess et paléosols - qui surmontent les graviers de la Haute Terrasse du Rhin dans les environs de Sierentz en France. D'après les résultats des datations, trois phases de pédogenèse, marquées dans des loess remaniés, se sont succédées durant le stade isotopique marin (SIM) 7 (245-190 ka). L'altération profondément marquée des graviers fluvio-glaciaires de la Haute-Terrasse, est attribuable soit à une phase tempérée précoce du SIM 7, soit à l'interglaciaire du SIM 9. Ces résultats, qui confèrent à la Haute-Terrasse de cette partie du fossé rhénan un âge minimal de $250 \mathrm{ka}$, sont en contradiction avec les estimations antérieures qui la plaçaient dans le SIM 6 (environ 150 ka). Considérés en regard de travaux récents sur d'autres sites, ils montrent en outre que le cadre chronostratigraphique des terrasses au nord des Alpes s'annonce plus complexe que ce qui a été admis jusqu'à présent.

\section{Introduction}

The Upper Rhine Graben (URG) is part of the European Cenozoic Rift system and geologically represents one of the most active areas in Central Europe (e.g., Ziegler 1994; Sissingh 1998; Laubscher 2001; Giamboni et al. 2004; Nivière et al. 2006; Ustaszewski \& Schmid 2007). Fluvial deposits in the region recorded both tectonic movements as well as variations in sedimentary dynamics caused by Quaternary climate change (e.g.,
Nivière \& Marquis 2000). Large parts of the southern URG, including the area of the city of Basel, are made up of plain surfaces of the Lower Terrace (Niederterrasse) that reach the Tertiary Midlands of the Sundgau (Fig. 1). Accumulation of the Lower Terrace sediments in the region took place during the Last Glaciation of the Alpine Foreland (Würmian), i.e. between 30-15 ka ago (Preusser et al. 2007; Kock et al. 2009a, b). The Tertiary hills of the Sundgau west of Allschwil and Sierentz are covered by loess and show a staircase like structure towards

\footnotetext{
${ }^{1}$ Institute for Prehistory and Archaeological Science, University of Basel, Spalenring 145, 4055 Basel, Switzerland.

${ }^{2}$ Institut für Geologie, Universität Bern, Baltzerstrasse 1 + 3, 3012 Bern, Switzerland.

${ }^{3}$ Pôle d'Archéologie Interdépartemental Rhénan, 67600 Sélestat, France.

*Corresponding author: Philippe Rentzel. E-mail: Philippe.Rentzel@unibas.ch
} 


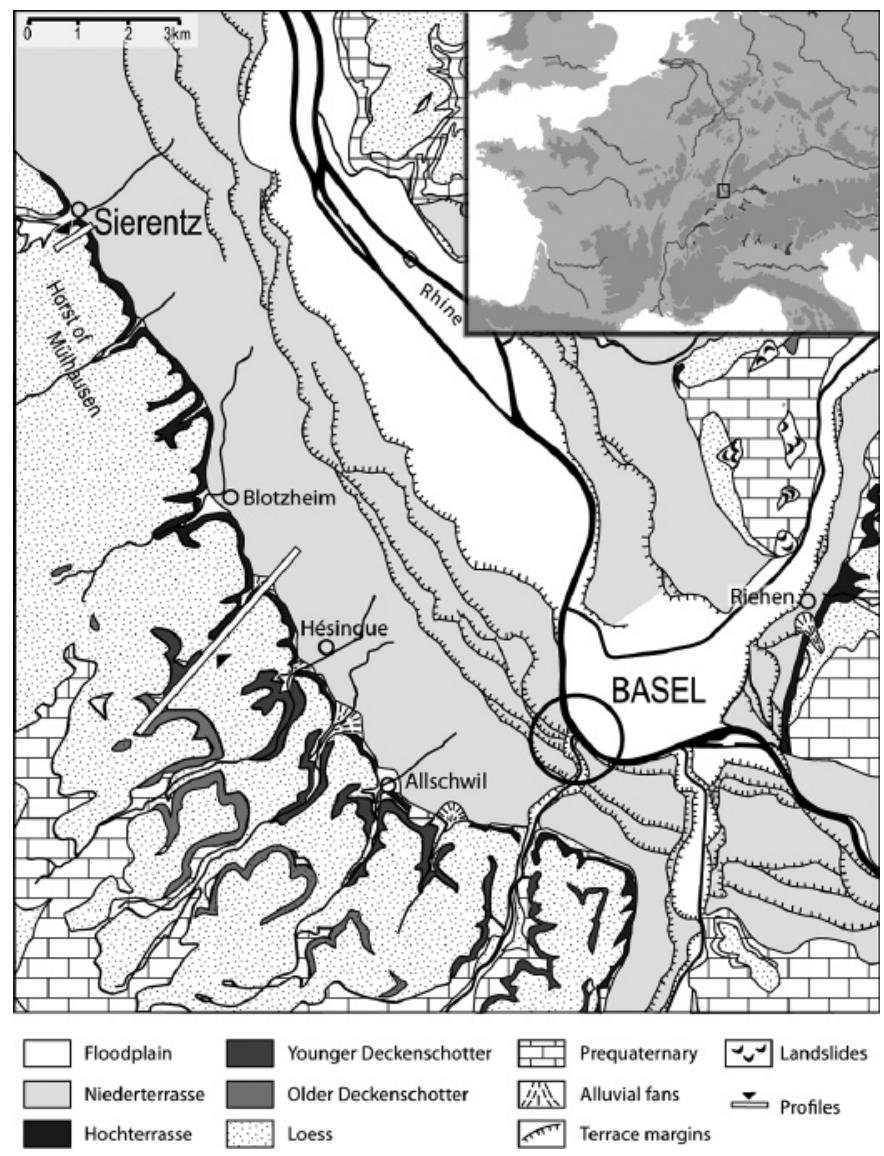

Fig. 1. Map showing the Quaternary geology of Basel region with the location of the loess/palaeosol sites of Sierentz-Monenberg, Allschwil-Ziegelei and Riehen-Gerhalde. Indicated is the position of the geological cross section near Hésingue (see Fig. 2) that runs crossways to the marginal zone of the Sundgau Midlands (modified after Wittman et al. 1970, Europe map after S. Fichtl - UMR 126-6).

the Rhine Valley (Fig. 2). The highest terrace levels have traditionally been correlated with the "Ältere Deckenschotter", the "Jüngere Deckenschotter" and the "Hochterrasse" of the classical Penck \& Brückner (1909) scheme (Fischer et al. 1971). Apparently, this succession reflects the Günzian, Mindelian and
Rissian glaciations as defined in the Bavarian Alpine Foreland. However, although this correlation appears straightforward, the application of the Penck \& Brückner (1909) scheme, especially outside the original key region in Bavaria, is now controversial. The main reason for the ongoing discussion is the paucity of reliable data that is available to constrain the age of the classical Alpine glaciations (cf. Häuselmann et al. 2007). Geological evidence from the Alps as well as from high resolution, deep-ocean sediment and Antarctic ice cores records actually indicates that much more glaciations occurred during the Quaternary than included in the Penck \& Brückner (1909) scheme. According to Schlüchter \& Kelly (2000) about 15 ice advances have been identified in Switzerland. Similar complex settings have also been observed for fluvial terrace flights in Europe, for regions such the Middle Rhine Area and the Lower Rhine Embayment (Boenigk \& Frechen 2006), the Rhenish Massif (Cordier et al. 2006), and northern France (Antoine et al. 2007).

To approach the problem of gravel terrace formation, investigation of cover sediments (mainly loess/palaeosol sequences) may be used to constrain the age of the underlying (glacio-)fluvial deposits, and hence indirectly constrain the age of Alpine glaciations. Pleistocene loess sequences are known from the SW part of the URG, in the Sundgau Midlands to the West of the city of Basel. A complex, but poorly dated $17 \mathrm{~m}$ thick loess/ palaeosol sequence is known from the former brick yard pit of Allschwil (CH), situated atop of a terrace attributed to "Jüngere Deckenschotter” (Bibus 1990; Beckmann 1991; Zollinger 1991). Geological observations from Riehen-Gerhalde (CH) also provide evidence of a complex loess/palaeosol sequence on top of the High Terrace (Jagher et al. 2003). Nevertheless no recent publication deals with the loess/palaeosol sequences on top of the High Terrace in the southern URG in detail.

The chronological position of the High Terrace between the Lower Terrace of the LGM and Lower Pleistocene "Deckenschotter" is rather controversial, due to the fact that Schlüchter \& Kelly (2000) conclude that the cold phase prior to the Last Interglacial, i.e. Marine Isotope Stage (MIS) 6 (about 190-135 ka ago), was characterised by an only limited glacial advance with glaciers barely reaching the margin of the Alps. Consequently, it is questionable if such a minor advance could have caused the formation of the prominent High Terrace in the URG, far away

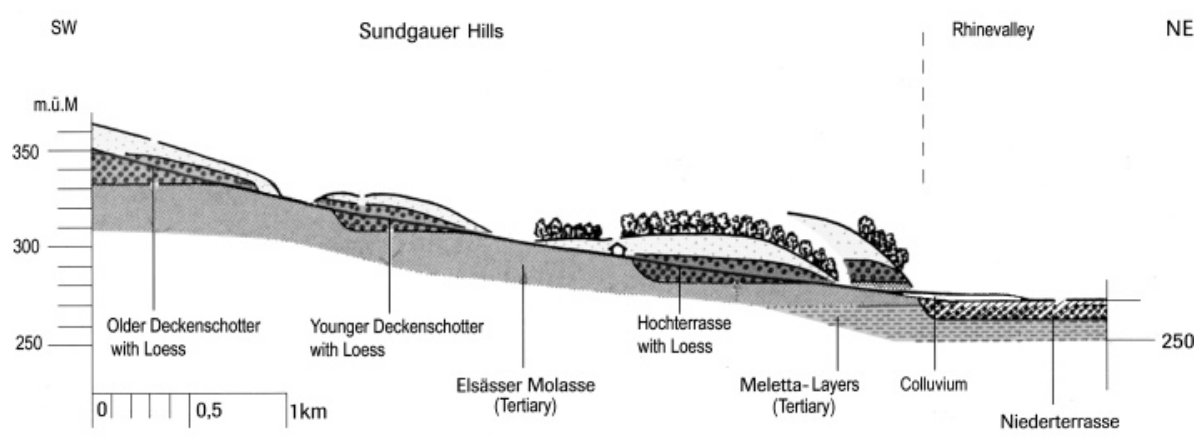

Fig. 2. Geological cross section near Hésingue through the marginal zone of the Sundgau Midlands following the stream Liesbach. The section is complemented by observations from further outcrops. On top of tertiary sediments a staircaselike succession of Quaternary deposits of River Rhine is found with decreasing age towards morphologically lower positions. The oldest gravel deposits covered with loess have been attributed to the Early Pleistocene "Deckenschotter". The High Terrace is also covered by loess and forms the margin of the Sundgau Midlands towards the Rhine Valley. To the NE follows the highest level of Lower Terrace with a fan build-up by reworked loess (modified after Fischer et al. 1971).

388 P. Rentzel et al. 
from the supposed glacial limits at that time. However, based on data from other areas such as Austria (e.g., van Husen 2004), MIS 6 is interpreted to represent the Rissian, hence a major glaciation that reached far into the Alpine Foreland, and was probably the most extensive ice advance out of the Alps during the Quaternary (at least in some regions). This would imply that the High Terrace could well have been formed during MIS 6. This interpretation is actually supported by stratigraphical analyses and luminescence dating of cover sediment sequences that reveal only one fully developed luvisol, correlated with the Last (Eemian) Interglacial, on top of the gravel of the High Terrace (Bibus 1995; Terhorst et al. 2002). However, Miara et al. (1996) distinguish between a lower and higher level of the High Terrace in the Riss Valley and demonstrated that deposition of the two gravel units was interrupted by at least one interglacial period. As a consequence, it appears that gravel accumulation attributed to the Rissian in its type region must represent more than one glacial phase, probably MIS 6 and MIS 8.

Road works during winter 2004/05 exposed an up to $22 \mathrm{~m}$ thick sequence consisting of gravel, loess and palaeosols on top of the High Terrace at Monenberg near Sierentz (France). Further outcrops became accessible during construction work on the plateau of Monenberg. The aim of the present study is to contribute to the question of the age of the High Terrace in this area, to better understand the origin of the cover sediments and to discuss both observations in the context of the regional landscape evolution and glaciation history of the Alps.

\section{Regional geological context}

A schematic cross-section at Hésingue (France, about $11 \mathrm{~km}$ from Sierentz) shows the staircase-like nature of gravel units above the Lower Terrace (Fig. 2). It illustrates that older fluvial deposits are only partially present from the margin of the Tertiary Midlands to the Rhine Valley. Only little information is available regarding the chronological position of the different terraces. Palaeomagnetic measurements of a sand layer within the "Jüngeren Deckenschotter" gravel unit at the former Allschwil quarry have an inverse magnetisation. This has been interpreted that the deposits are older than the Brunhes epoch, hence older than $780 \mathrm{ka}$ (Zollinger 1991). Such an age for the "Jüngeren Deckenschotter" seems to be confirmed by the complex and $17 \mathrm{~m}$ thick sequence of cover sediment including at least five well developed luvisols. The Allschwil sequence represents an alternation between phases of loess deposition, soil formation and erosion that has been identified at other Pleistocene sites in the URG area (Rousseau et al.1998; Antoine et al. 2001). However, more recent investigations have demonstrated that there have been several phases of inverse magnetisation during the Brunhes epoch (Lund et al. 2006). The presence of inverse magnetisation in a sedimentary record is therefore of limited value for chronostratigraphic interpretations as it may represent any of these reversal events.

The outcrops at Sierentz provide insight into the cover sediments on top of the High Terrace. This stratigraphy is considered to represent only the younger part of the Allschwil sequence. In this area, the extension of the High Terrace can be followed from Allschwil to Sierentz and further to the NW. It is visible as a prominent break in slope between the Lower Terrace and the Sundgau Midlands (Théobald 1958; Fischer et al. 1971). At Sierentz, the highest level of the Lower Terrace, deposited during the Late Würmian (Wittmann 1961; Rentzel 1997; Kock et al. 2009a, b), is $2 \mathrm{~km}$ wide and covered by an alluvial fan made up by reworked loess (Théobald 1958; Wittmann et al. 1970). Outside the fan, gravel of the uppermost level of the Lower Terrace are affected by Late Glacial and Holocene soil formation, leading to a luvisol with a decalcification depth of not more than $1 \mathrm{~m}$ (Wittmann 1961). Pedological investigation in the brickyard of Allschwil (Zollinger 1991) and in the quarry of Dittingen-Schachleten (Rentzel et al.1999) have proven the existence of Holocene luvisol on top of Upper Pleniglacial and Late Glacial loess derivates.

According to Fischer et al. (1971), a NNE-SSE running fault follows along the base of the slope of the High Terrace separating the Sierentz Graben from the Mülhauser Horst. However, this fault could not be confirmed by seismic measurements (Nivière \& Winter 2000), but seems to be evident in a new outcrop of the High Terrace near Blotzheim (Kock 2008). Further faults parallel to this have been identified on the Sundgau Midlands (Théobald 1958).

Near Sierentz, Lower Terrace deposits covered by reworked loess are found to the East beyond the main road RD 66 at an elevation of about $258.4 \mathrm{~m}$. Towards the West, the land surface climbs slowly in elevation. The surface of the High Terrace is about $6 \mathrm{~m}$ above the Lower Terrace. The investigated profile follows the base of a flat depression that climbs towards the Monenberg plateau. This NE dipping erosion channel is in its upper part filled up by humic-rich loess colluvium.

\section{Materials and methods}

Geological field work was carried out in 2004 including logging and sampling of the sections with respect to their stratigraphy, sedimentology, periglacial features and pedological horizons (Van Vliet-Lanoë 1987; Arbeitsgruppe Boden 2005; WRB 2007). Samples for sedimentological and micromorphological analyses as well as for infrared stimulated luminescence (IRSL) dating were taken.

\section{Micromorphology and sedimentology}

For micromorphological studies, ten samples have been taken in plastic boxes during field work. They were later impregnated with epoxy resin and cut with a diamond saw. A series of 16 covered thin sections $(4.7 \mathrm{~cm} \times 4.7 \mathrm{~cm})$ was prepared by Th. Beckmann, Braunschweig (Germany). The slides were examined under a polarising microscope and described according to Bullock et al. (1985) and Courty et al. (1989). 29 bulk samples were treated for classical grain-size analyses of the sand and gravel fractions using sieves (Rivière 1977; Hadjouis 1987). 


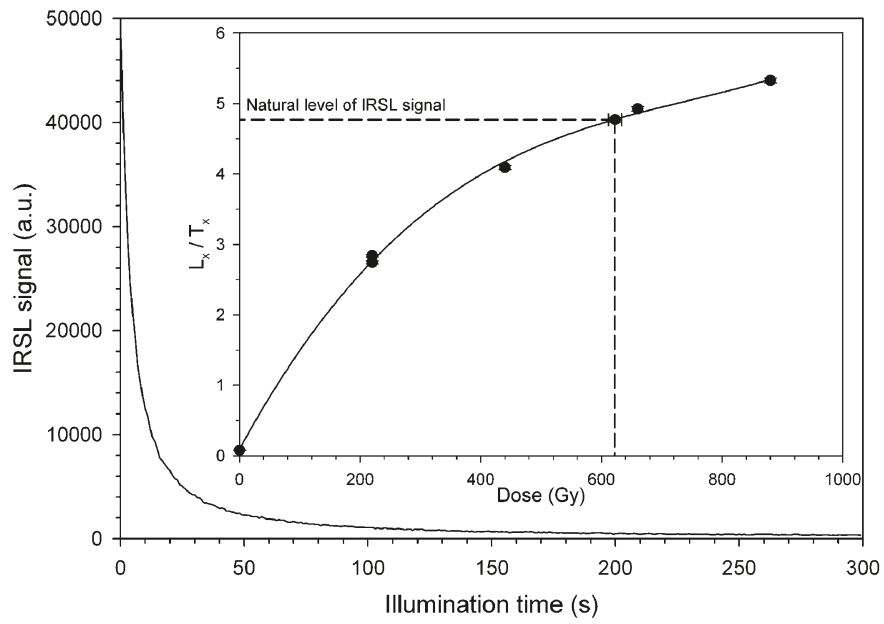

Fig. 3. Example of an IRSL depletion curve and a dose response curve for sample SIE 11.

The silt and clay fractions were measured with a laser system (Malvern, MS20). Geochemical measurements of the sediment comprised total carbonate content, $\mathrm{pH}$ (in a $\mathrm{KCl}$ solution) and organic content by loss on ignition (Brochier \& Joos 1982).

\section{Luminescence dating}

Infrared Stimulated Luminescence (IRSL) was used to date the last sunlight exposure of the sediment grains (cf. Aitken 1998; Preusser 2004a; Preusser et al. 2008). The method utilises a light-sensitive signal in feldspar grains that is zeroed by daylight during sediment transport and raised during burial, when the grains are sealed from light. The latent IRSL signal is induced by the interaction of naturally occurring radioactivity with electrons in the feldspar crystal. For dating, the amount of absorbed dose is quantified by comparing the natural IRSL signal with that resulting from artificial irradiation (given knowndoses). The result of this IRSL measurement, called palaeodose, is divided by the dose rate within the sediment.

Samples for palaeodose measurements were obtained by forcing opaque cylinders into freshly cleaned sediment exposures. Additional material has been taken for dose rate measurements. In the red-light laboratory, the outer part of sediment in the cylinders was removed and discarded. The material from the inner part of the cylinder was recovered and treated with $10 \%$ $\mathrm{HCl}, 30 \% \mathrm{H}_{2} \mathrm{O}_{2}$ and $\mathrm{Na}$-oxalate to remove carbonates, organic material and disperse clay. The fraction 4-11 $\mu \mathrm{m}$ was isolated by settling using Stokes' law. Between 2-3 mg of material were deposited on $1 \mathrm{~mm}$ stainless steal discs from acetone suspension. IRSL measurements were made on a Ris $\varnothing$ DA-18 reader using an interference filter with a peak emission at $410 \mathrm{~nm}$. The single-aliquot regenerative dose (SAR) protocol has been used for determination of palaeodose using the adjustments for feldspar as described by Preusser (2003). IRSL was recorded during a $300 \mathrm{~s}$ exposure to IR diodes (at $50{ }^{\circ} \mathrm{C}$ ) (Fig. 3). The first $5 \mathrm{~s}$ of the signal were integrated for palaeodose calculation and the last $50 \mathrm{~s}$ were subtracted as background from this signal. Three regenerative dose groups where used (plus zero dose) and the lowest dose was measured twice, at the beginning and at the end of the SAR cycle (Fig. 3, inset). The ratio of this recycling measurement is for all samples with $10 \%$ of unity $(>90 \%$ are within $5 \%$ ). Dose recovery, preheat tests and thermal transfer tests have been performed to investigate the suitability of the applied measurement parameters, in particular preheat. These tests reveal a good recovery of the given dose (ratios between 1.00 and 1.05) without any significant effect of preheat (Fig. 4), negligible thermal transfer but a slight increase of palaeodose with increasing preheat (Fig. 5). No further increase of palaeodose is observed for temperatures above $270{ }^{\circ} \mathrm{C}$ and this is interpreted to reflect the removal of thermally instable components of the IRSL signal (Li 1991). For all measurements (including test dose) preheating at $290{ }^{\circ} \mathrm{C}$ for $10 \mathrm{~s}$ has been applied. For each sample five aliquots have been measured so that mean and standard error (SE) could be calculated. Increasing the number of aliquots will not improve the quality of ages as, firstly, the reproducibility of these particular measurements is excellent (SE partly $<1 \%$ ) and, secondly, partial bleaching can not be detected from aliquots containing several hundreds to thousands of luminescence grains (Wallinga 2002), as is the case in fine-grain dating. A possibility to investigate if the IRSL signal was set to zero prior to deposition is to plot the palaeodose as a function of illumination time (shine plateau test) (Li 1994). However, this approach may not always reveal incomplete bleaching as it can be masked by other phenomena (e.g., Aitken 1998; Fiebig $\&$ Preusser 2007). We have checked this approach for selected samples from Sierentz and the results are discussed below.

The concentrations of dose rate relevant elements $(\mathrm{K}, \mathrm{Th}$, U) have been measured by high-resolution gamma spectrometry in the laboratory (cf. Preusser \& Kasper 2001). Age calculation was carried out using the ADELE V1.06 program (Kulig

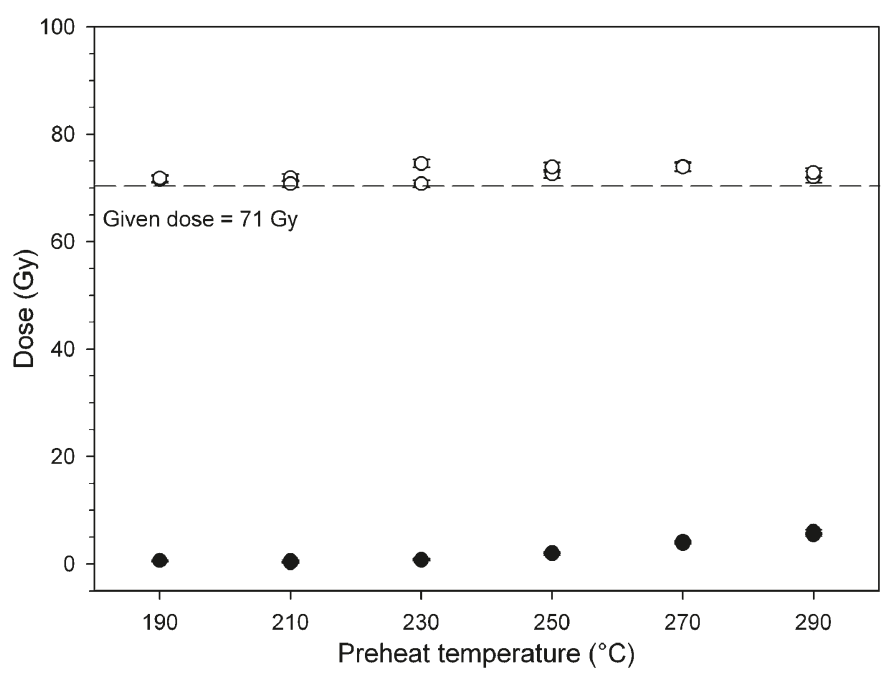

Fig. 4. Plot of recovered dose and thermal transfer for different preheat temperatures for sample SIE 11.

390 P. Rentzel et al. 


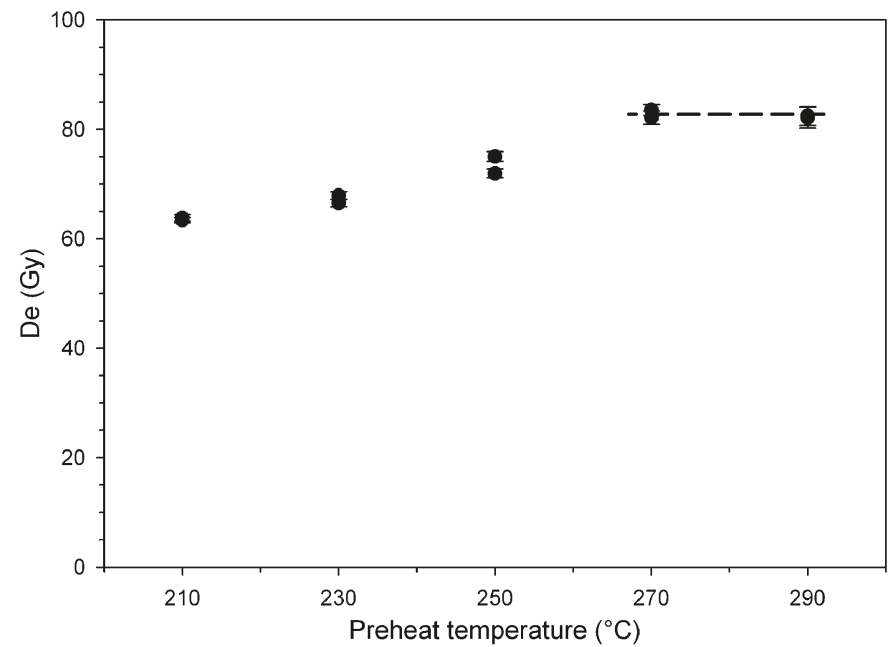

Fig. 5. Plot of palaeodose versus preheat temperature for sample SIE 11. Up to $270^{\circ}$, an increase of palaeodose with rising preheat temperature is observed, which implies the presence of instable signal components. For dating, preheating at $290{ }^{\circ} \mathrm{C}$ has been used.

2005). Present day depth was used for calculating the contribution of cosmic rays to the total dose rate and we corrected for geographical latitude and elevation. A mean sediment moisture during burial of 20-30\% has been assumed and we used an alpha-efficiency of $0.07 \pm 0.02$ (Preusser 1999).

\section{Results}

\section{Stratigraphy of the Monenberg sequence}

According to field observations as well as micromorphological and sedimentological analyses, the section along the outcrop at the Monenberg site can be subdivided into nine depositional units and soil horizons (U1-U9) that are described in the following (Fig. 6a, 6b, Fig. 7, Fig. 8 a-f). The results of sedimentological analyses are summarized in Figures 9 and 10.

High Terrace with palaeosol (U9), (Fig. 6a)

The High Terrace is subdivided into a complex of three subunits: 1) at the base a weathered glaciofluvial gravel with Alpine components (U9c), 2) a reddish palaeosol (U9b) and 3) a cover bed of reworked loamy gravel (U9a). The base of the whole sequence is build up by decalcified sandy gravel (U9c) that is locally cemented by pedogenic carbonates (petrocalcic horizon). This layer is followed by a $0.7 \mathrm{~m}$ thick reddish-brown argic horizon (Bt-horizon, U9b) with highly disintegrated crystalline pebbles and lenses of loamy sand. From a pedological point of view, unit $9 \mathrm{~b}$ reflects a strongly developed luvisol, which is truncated in its upper part and covered by reworked soil material (U9a). The sharp and undulating upper surface of the layer U9a indicates a further erosional phase.
Reworked loess with cambisol (U8), (Fig. 6a)

The High Terrace complex is topped by $0.5 \mathrm{~m}$ decalcifed loesslike sediment containing some fine gravel. According to micromorphological analyses this layer represents a gleyic cambisol that developed on reworked loess with gravel and that contains pellets of a pre-existing luvisol (Fig. 8a). The soil shows clear evidence for strong hydromorphic overprinting leading to a reticulated microfabric and in-situ iron oxide impregnations.

Laminated slope-washed sands (U7) with palaeosol (U6), (Fig. 6b)

The over $2 \mathrm{~m}$ thick laminated sediment is divided into a lightbrown lower and a dark-brown upper zone. Characteristic for this sediment is an alternation of calcareous loess and brown loamy loess containing rounded soil fragments of cambisols and luvisols (Fig. 8b). Microscopic analyses reveal thin horizontal layering and evidence for frost action as well as for gelifluction, implying transport in a low energy system under periglacial conditions (Van Vliet-Lanoë 1987). Mollusc shells, fragmented calcium carbonate concretions, accumulations of calcite biospheroids and reworked iron oxide concretions are frequently found. Well-developed sub-parallel normal faults push trough the layer in a fan-like style and reach into the palaeosol (U6) on top (Fig. 6b). The faults are dipping towards the $\mathrm{NE}$, in direction of the Rhine Valley, and show an offset of a few millimetres. They could either document gravitational sliding or tectonic activity in context of subsidence in the Sierentz Graben, taking place after accumulation of layer U7 but prior to the development of soil U6.

The upper part of the slope-wash sediments has been affected by pedogenesis (palaeosol U6) that is characterised by a yellowish-brown argic horizon with a diffuse lower limit. The clayey silt shows a sub-angular blocky structure and bears several iron and manganese oxide impregnations. Due to its micromorphological characteristics it is interpreted as the remains of a luvisol with redoximorphic features (Fig. 8c). The sharp, subhorizontal upper surface points towards prominent erosional processes after soil formation.

Pedosediment (U5) with chernozem (U4), (Fig. 6b)

In the central part of the profile, a heterogeneously layered unit of brown loam, reworked carbonate concretions and thin layers of reworked loess is found on top of the erosional surface (U6). Microscopical investigations reveal that most of layer U5 (Fig. 8d) consists of pedosediment and reworked material of a luvisol (from layer U6?). The accumulation of unit U5 apparently took place during a phase characterised by massive backwards cutting erosion of loess and palaeosols from the plateau. After sedimentation, the upper part was affected by the formation of a dark steppesoil with a mollic horizon (chernozem, U4). Microscopical analyses revealed a decalcified humiferous loess with iron impregnations that has been affected by bioturbation 

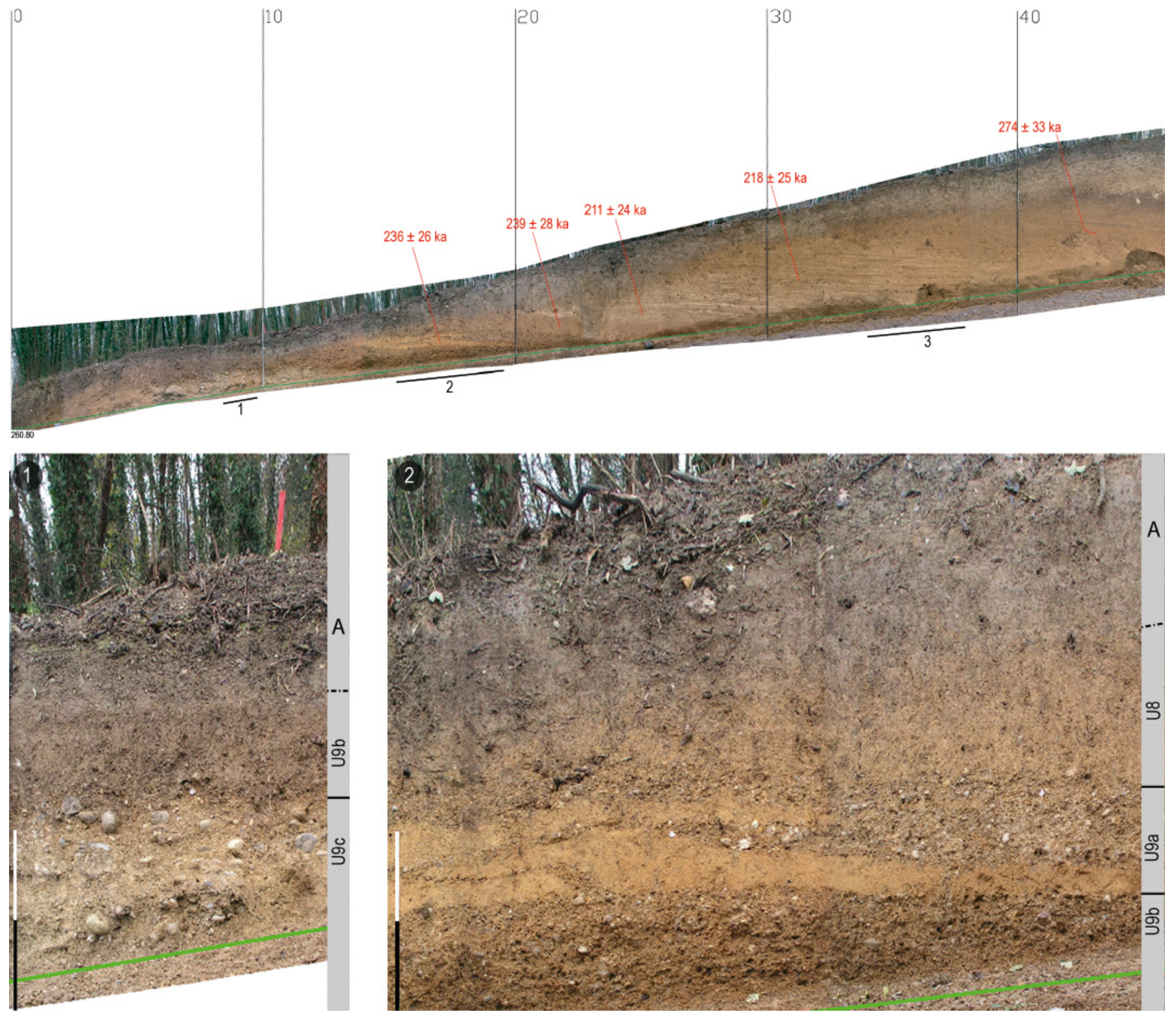

Fig. 6a. Sierentz Monenberg, equalised photograph of the outcrop, 0-46 m with details below. A: modern soil.

and frost (Fig. 8e). Deformation structures and hummocks found in the upper part of the soil indicate that it was overprinted by solifluction. Towards the south, the chernozem shows a reduced thickness and is interfingered with laminated loess of unit U3a.

Loess (U3b) and laminated loess with frost cracks (U3a), (Fig. 6b)

This yellowish-brown reworked loess U3a is about $3 \mathrm{~m}$ thick and fills up a shallow depression that apparently reflects a SW-NE running thalweg. In the eastern part of the section, the layered loess interfingers with the displaced chernozem (U4). Towards the west, the reworked loess is situated on top of in-situ loess (U3b), but the boundary is not well exposed. Unit U3a is a fine-layered, geliflucted loess derivate containing reworked soil aggregates (Fig. 8f). Within the outcrop, several parallel frost cracks have been observed reaching a length of $2 \mathrm{~m}$. They are dipping in the direction of the slope and show weak deformation structures in contact with the lamination. These periglacial phenomena caused by frost and cryo-desiccation are micromorphologically reflected by a typical platy structure (Van Vliet-Lanoë 2004). 

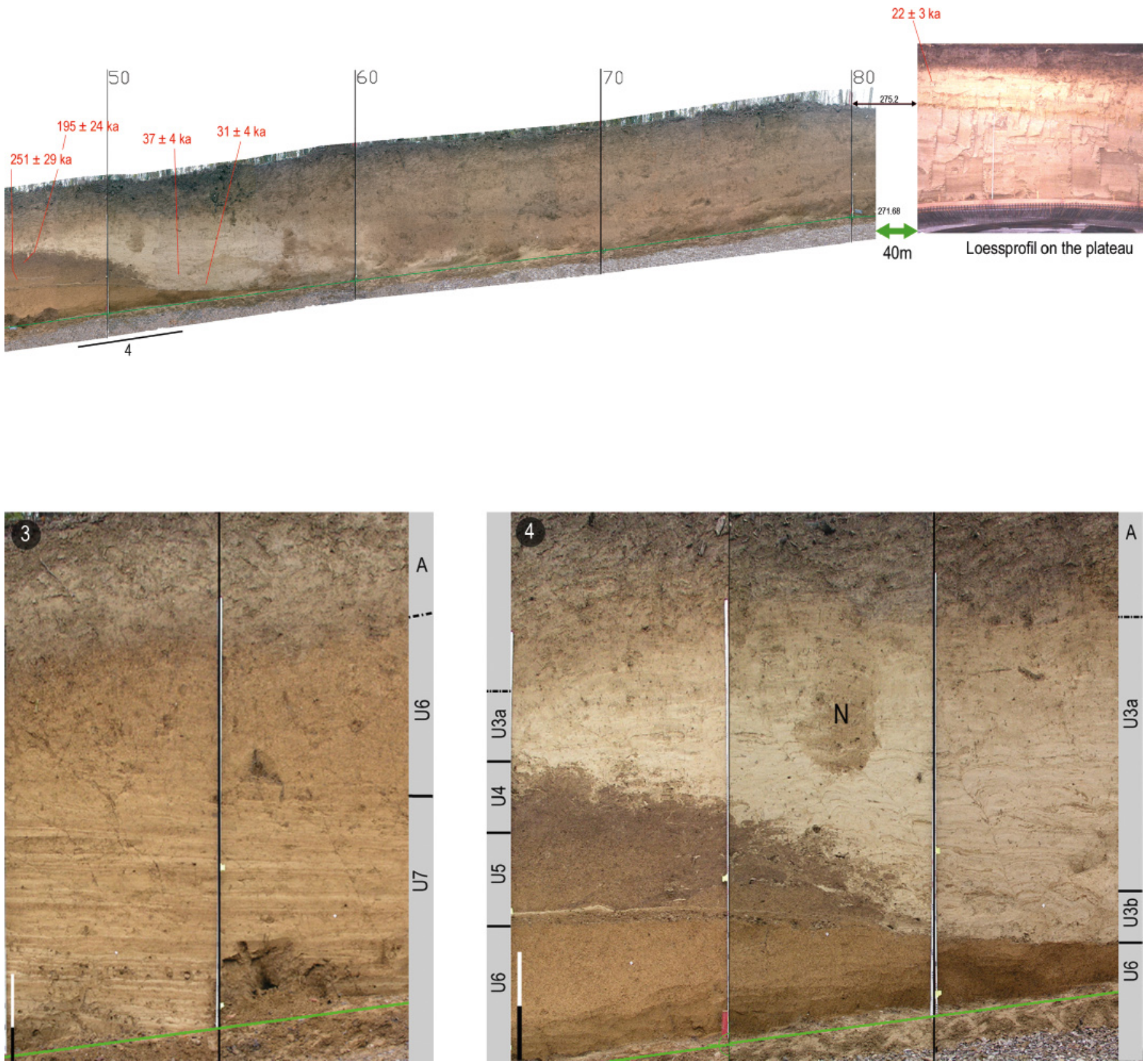

Fig. 6b. Sierentz Monenberg, equalised photograph of the outcrop, 46-81 m, and loessprofile with details below.

Loess (U2)

Due to erosion, this yellowish calcareous loess is only locally preserved under colluvium. On the top of the Monenberg plateau the loess reaches a thickness of more than $5 \mathrm{~m}$ and contains at least two oxidised horizons with accumulation of secondary calcium carbonate. These horizons are interpreted to reflect initial soil formation of a tundra gley (cf. Antoine et al. 2001). The geometry of the strata implies the presence of a northward running erosional depression, which eroded the loess from the main section. The calcareous loess of unit U2 is unconformably covered by Holocene colluvium in its upper part.

\section{Colluvium (U1)}

In the SW part of the main profile reworked soil horizons have been found resting on the undulating surface of the loess (U2). The base of this over $4 \mathrm{~m}$ thick series of loess colluvium consists of brown loamy silt (U1e) with reworked soil material (luvisol) and contains Neolithic ceramics. The younger loess-colluvium U1c, layered parallel to the slope, contains Prehistoric to Ro- 


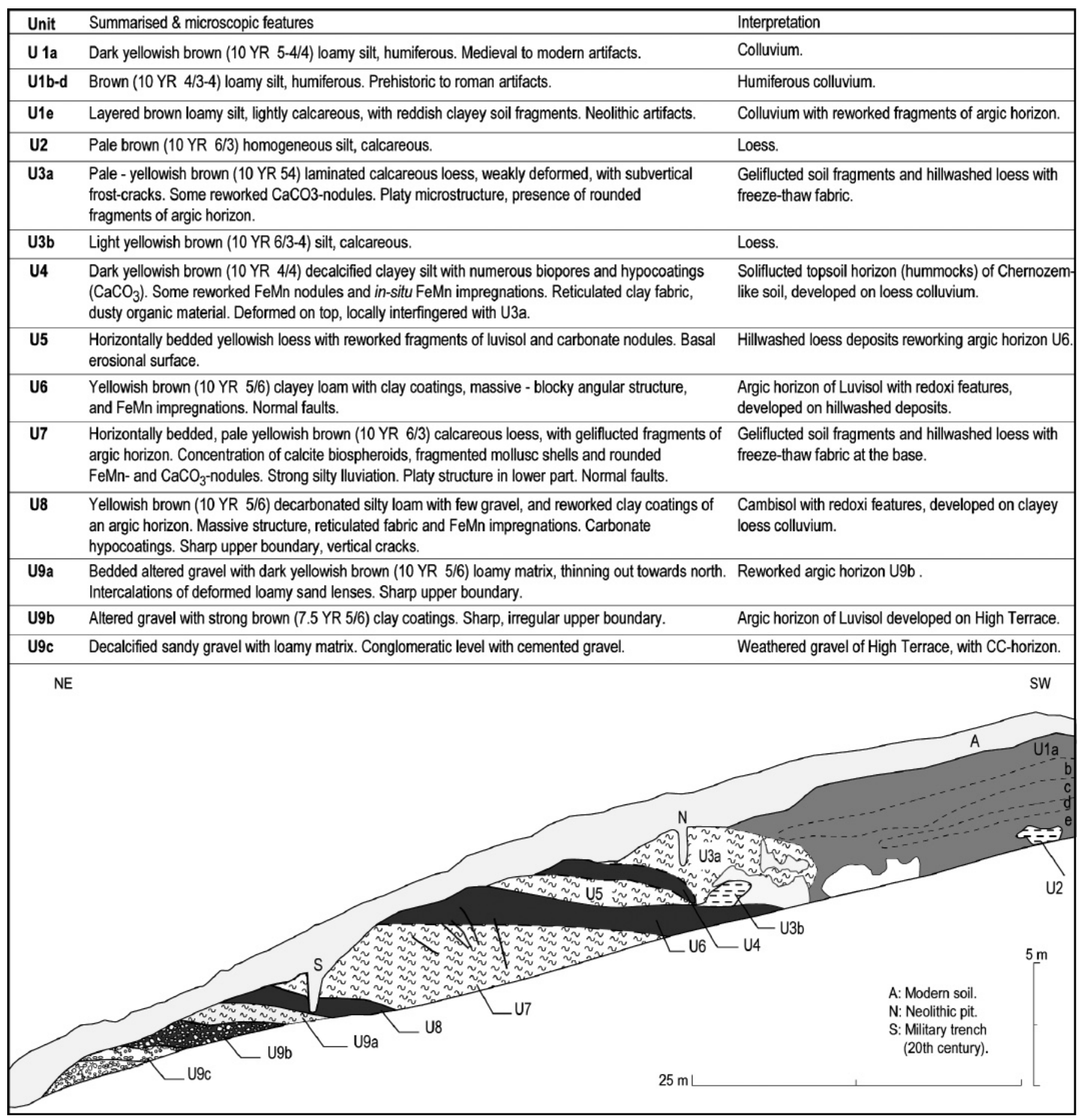

Fig. 7. Sierentz Monenberg, description of the units, interpretation of the sediments, periglacial features and soils (according to Van Vliet-Lanoë 1987; WRB 2007; Munsell 1992).

man artefacts. Its top is covered by a $50 \mathrm{~cm}$ thick humiferous colluvium (U1b) that is dated by archaeological findings to the first century AD. The uppermost part of the section is built up by Medieval to Modern colluvium (U1a).

\section{IRSL datings and their interpretation}

IRSL dating gave two sets of clusters of ages (Fig. 11). The first set of IRSL ages is between 190 270 ka for samples from the basal part of the sequence with the (reworked) soil material. The second set is between ca. 20-40 ka for samples from the 

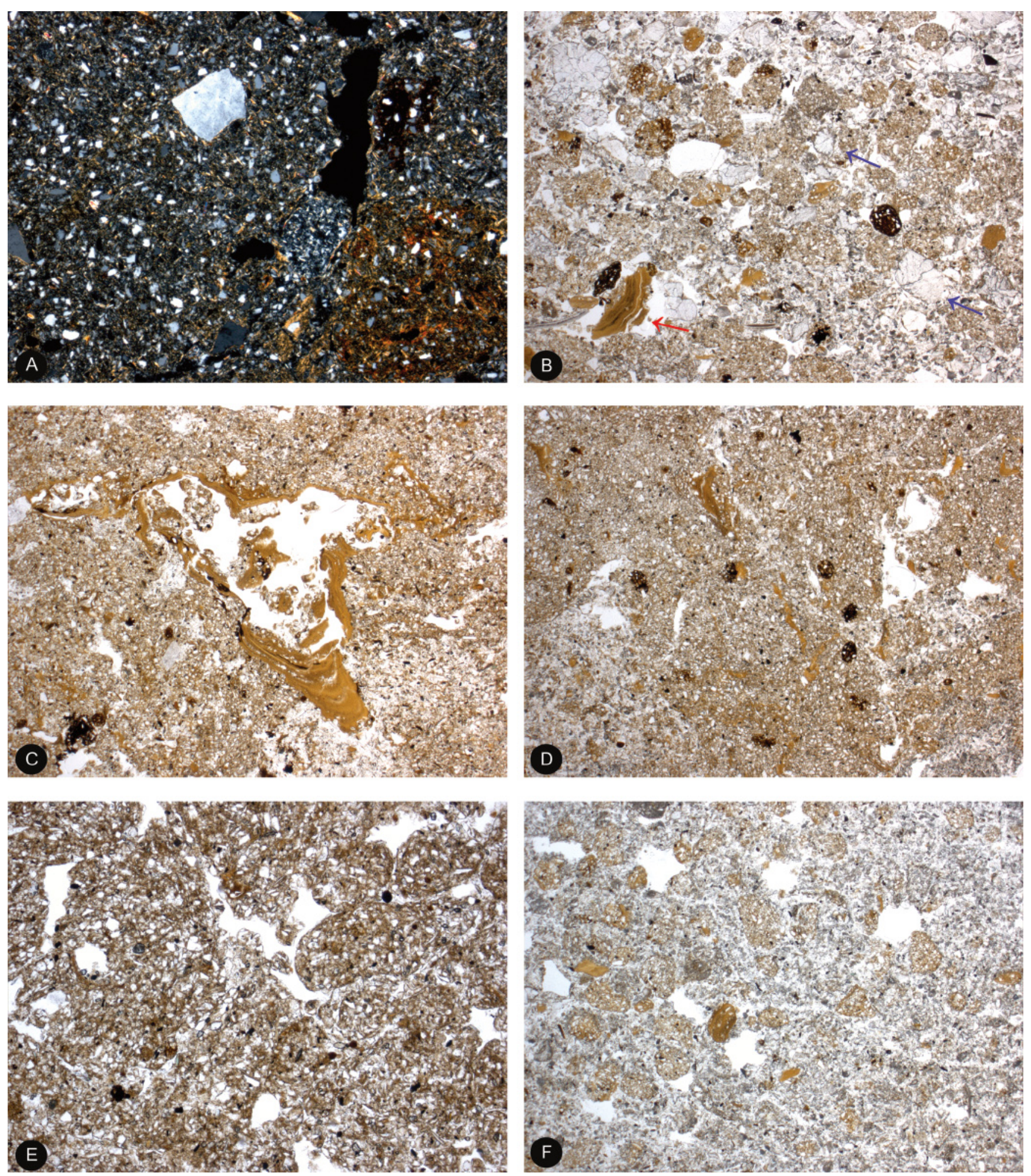

Fig. 8. Photomicrograph of thin sections a) Clayey cambisol U8 showing reticulated microfabric due to hydromorphic overprinting. Note reworked soil fragment at the right bottom. (Sie05/M3. Frame length $2.3 \mathrm{~mm}$, XPL). b) Hillwashed sediment U7 composed of geliflucted soil pellets of cambisol and luvisol (red arrow). Note also reworked calcite biospheroids (blue arrow). (Sie05/M2.1. Frame length $4.5 \mathrm{~mm}, \mathrm{PPL}$ ). c) Luvisol U6 with well developed clay coatings and dark FeMn impregnations. (Sie05/M9. Frame length $4.5 \mathrm{~mm}$, PPL). d) Reworked loess U5 with disrupted clay coatings of luvisol U6 (?) and rounded black FeMn nodules. (Sie05/M5.1. Frame length $4.5 \mathrm{~mm}$, PPL). e) Chernozem-like soil U4, a highly bioturbated humiferous and decarbonated loess. (Sie05/M4.2. Frame length $2.3 \mathrm{~mm}$, PPL). f) Laminated loess U3a with geliflucted pellets of a reworked luvisol. Note platy structure caused by frost. (Sie05/M4.1. Frame length $4.5 \mathrm{~mm}, \mathrm{PPL})$. 


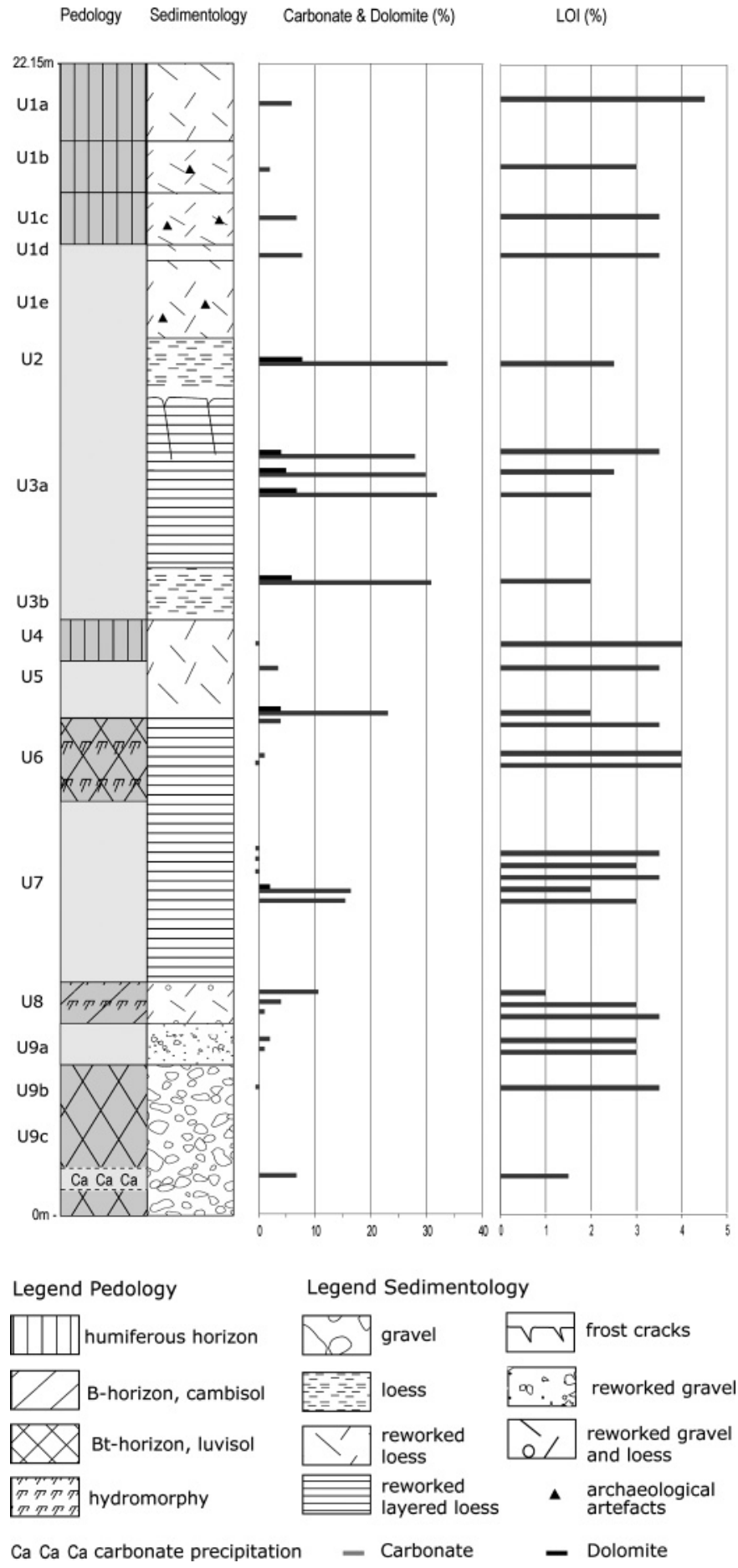

Fig. 9. Results of sedimentological, pedological and geochemical analyses.

upper part of the sequence that is characterised by loess and reworked loess. IRSL ages for reworked sediment on top of the gravel are $236 \pm 26 \mathrm{ka}$ (SIE1) and $239 \pm 28 \mathrm{ka}$ (SIE2) for the brown soil. Two IRSL ages for slope-wash loess derivates of Unit 7 are $211 \pm 24 \mathrm{ka}$ (SIE3) and $218 \pm 25 \mathrm{ka}$ (SIE4) and

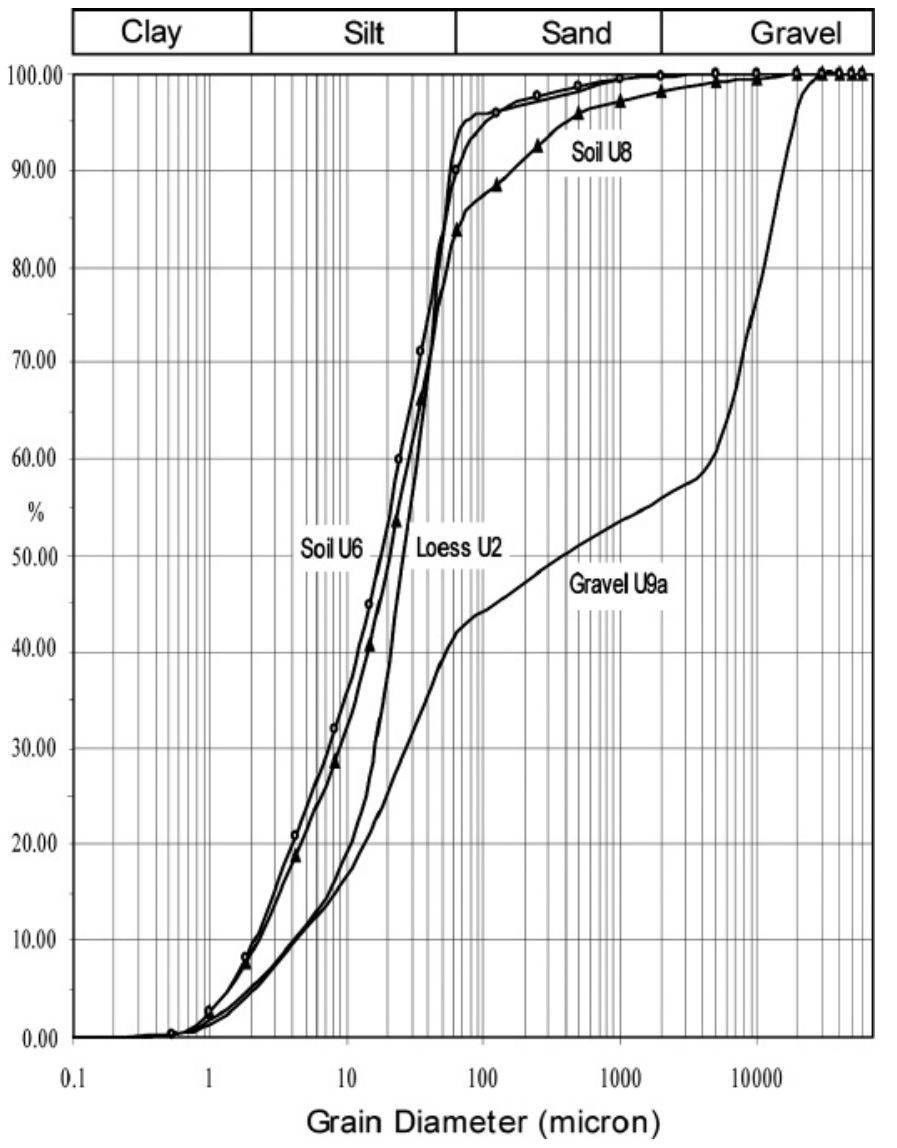

Fig. 10. Results of grain-size analyses.

are consistent within error. For horizons U6 and U5, which are characterised by reworked soil material and loess revealing a large number of sediment pellets according to micromorphology, IRSL ages of $274 \pm 33 \mathrm{ka}$ (SIE6) and $251 \pm 29 \mathrm{ka}$ (SIE8) have been determined. The age for the sediment on which the chernozem (U4) developed is dated to $195 \pm 24 \mathrm{ka}$ (SIE7). For the reworked loess above the major hiatus between unit 4 and 3 two consistent IRSL ages of $31 \pm 4 \mathrm{ka}$ (SIE 18) and $37 \pm 4 \mathrm{ka}$ (SIE11) have been obtained. The uppermost sample (SIE17) from in-situ calcareous loess is dated to $22 \pm 3 \mathrm{ka}$.

One question that arises is if the ages could be overestimated due to incomplete bleaching of the IRSL signal prior to deposition. To investigate this possibility, so-called shine plateau test have been carried out, which should show an increase of palaeodose with integrated illumination time if samples have been incompletely bleached. For none of the samples such an increase could be observed (Fig. 11). However, the plot of palaeodose versus illumination time will also be flat if the material of a sample (or part of it) was not-at-all exposed to daylight. This can happen if sediment is transported in the form of aggregates (pellets). Evidence for the presence of such pellets is available for samples SIE6 and SIE8. In this horizon, sediment pellets with a diameter of up to $1 \mathrm{~cm}$ have been found (Fig. 8a). 


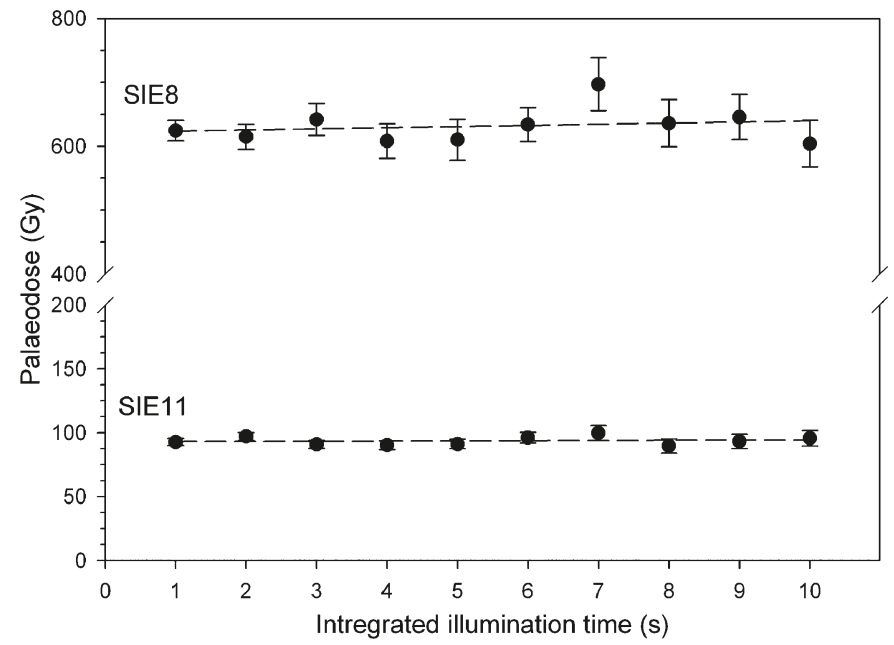

Fig. 11. Example shine plateau plot for samples SIE 8 and SIE 11.

Ages for the two samples from this horizon are hence interpreted to represent maximum estimates due to likely incomplete bleaching of the IRSL signal. The material is probably derived from older palaeosol material up-slope. Concerning the other samples, it has been demonstrated by a substantial number of case studies that partial bleaching is rarely important for Holocene colluvial sediments (cf. Fuchs \& Lang 2009). In cases where partial bleaching was present, the offset between the apparent and the independently constrained age of the samples has mainly been in the order of not more than a few thousand years, which would be negligible for the lower part of the sequence under consideration here.

Another potential uncertainty regards the reliability of IRSL ages $>150 \mathrm{ka}$. In many previous studies that have used IRSL for dating loess/palaeosol sequences, a systematic age underestimation has been observed for sediments older than Last Interglacial (e.g., Frechen et al. 1999). However, these studies used multiple aliquot methodology that provides, in contrast to the SAR protocol applied here, very limited information about changes in luminescence properties during measurements. SAR methodology also allows much better approaching the saturation level of the IRSL signal. Hence, the experience from previous studies regarding the upper dating limit of IRSL is of rather limited validity for the present project. A problem in evaluating the reliability of IRSL $>150 \mathrm{ka}$ is the almost absence of independent age control in this time range, but a few case studies exist from the Alpine Foreland for comparison. For lacustrine sediments from northern Switzerland, Anselmetti et al. (submitted) report consistent polymineral IRSL and quartz Optically Stimulated Luminescence (OSL) ages down to $180 \mathrm{ka}$, implying that IRSL does not systematically underestimate the deposition age. Preusser et al. (2005) dated the Meikirch site in the Aare Valley and got IRSL and post-IR OSL ages in agreement with age constrains deduced from palynostratigraphy and correlated the sequence with MIS 7. Loess deposited prior to
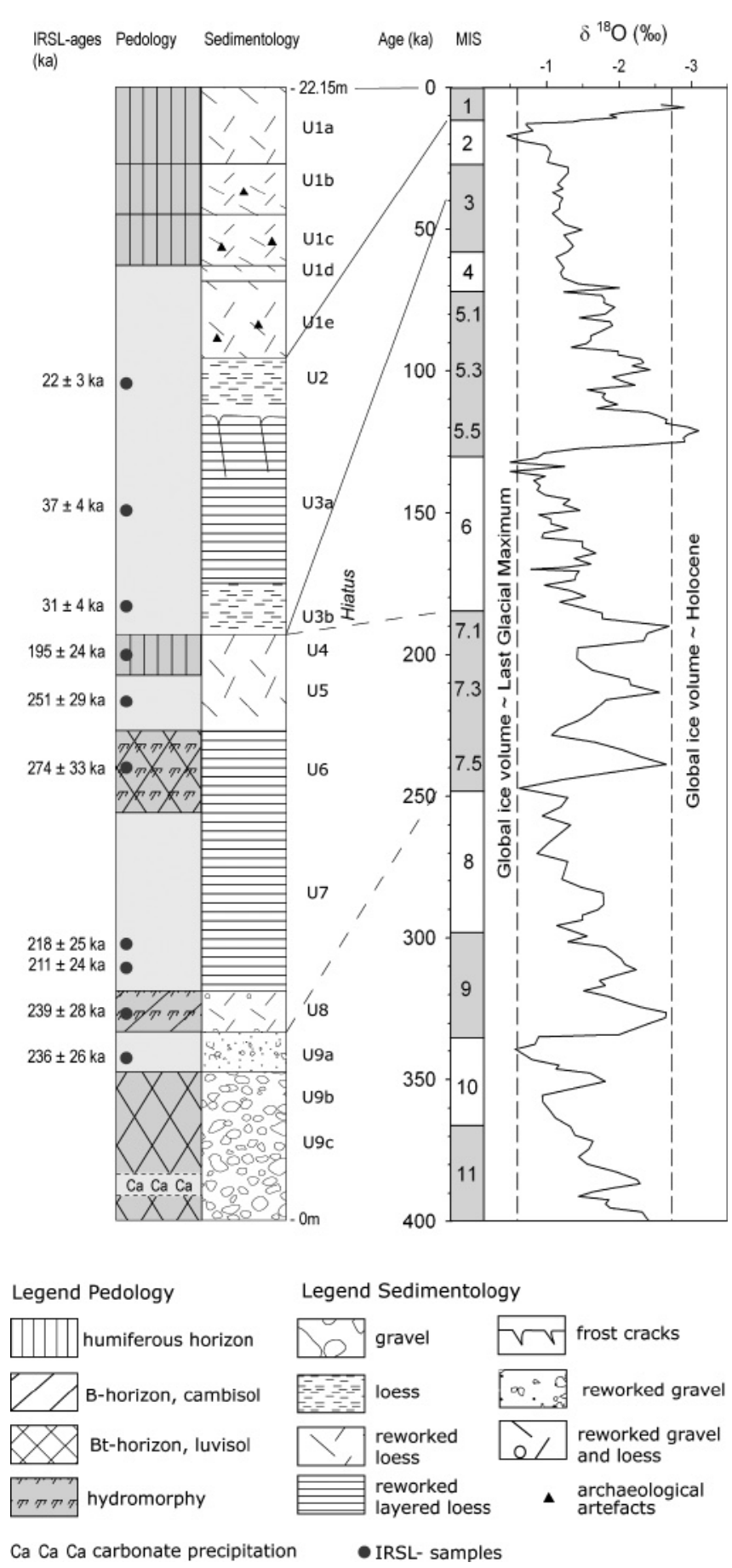

Fig. 12. Correlation of the Sierentz site with the oxygen isotope from the Maldives as a measure of global ice volume (Bassinot et al. 1994). The lines indicate periods of large (Last Glacial Maximum = Würm sensu stricto) global ice masses during MIS 2, 6, 8 and 10 and times of low (Holocene) global ice cover during MIS 1, 5.5, 7.1, 7.3, 7.5 and 9. These periods are interpreted to reflect glacial and interglacial periods on a global scale. The tripartition of MIS 7 into three individual interglacials is apparently reflected by soil development at Sierentz and confirmed by IRSL dating. As a consequence, the minimum age for the formation of the High Terrace at Sierentz is MIS 8. Soil development in the upper part of the gravel itself may correlate with either MIS 7.1 or MIS 9. If the latter correlation is correct, the minimum age of the terrace gravel would be MIS 10 . 
the Last Interglacial in the section of Wels (Austria) is apparently also not underestimated (Preusser \& Fiebig 2009), as it is in agreement with pedostratigraphy. As a consequence, we consider the IRSL ages estimates presented here, with the two exceptions discussed above, as being likely reliable.

\section{Discussion}

As the constraints concerning the age of the horizons at Sierentz become less confident towards the lower part of the sequence, the discussion about the age of the cover sediments and the gravel starts from the top, proceeding from young to old.

The archaeological findings of U1 clearly indicate a Holocene age of the colluvium that apparently comprises several periods from the Neolithic to Modern Times. U1b represents a dark humiferous topsoil which reflects land use during the late Roman period or early Medieval times. U1e, a colluvium with Neolithic artefacts, comprises several reworked fragments of the Late-Glacial/Early Holocene luvisol. The latter, developed on loess U2, has been completely eroded.

The in-situ loess layer below dated to $22 \pm 3 \mathrm{ka}$ falls into the maximum of the last glaciation of the Alps, a period that was characterised all over central Europe by loess accumulation (cf. Frechen et al. 2003; Preusser 2004b). The two ages for the reworked loess unit U3a fall into the late Middle Würmian (MIS 3), hence a period that is in many loess sequences characterised by reworking of older sediments and frequent hiatuses (e.g., Antoine et al. 2001; Boenigk \& Frechen 2001; Frechen 1999; Guélat 2000). IRSL ages indicate that most of MIS 3 as well as all of MIS 4-6 are not recorded at Sierentz (Fig. 12). This hiatus is probably due to erosion as suggested by the geometry of the strata.

The lower part of the sequence comprises four soil horizons of which U9b (luvisol on top of deeply weathered gravel), U6 (luvisol) and U4 (chernozem) represent, according to micromorphology, in-situ soil developments. Cambisol U8 shows evidence for soil development in a previously weathered loesspedosediment, followed by hydromorphic overprinting. According to IRSL dating, the lower part of the cover sediments and the intercalating soils (U8/U6/U4) developed during MIS 7. Two of the soils (U8/U6) represent weathering under pronounced warm (interglacial) conditions and the chernozem U4 reflects a steppe-like environment as typical for well-developed interstadials (i.e. Early Würmian Interstadials, cf. Preusser 2004b).

For the Alpine Foreland, it is usually expected that MIS 7 comprises only one phase of interglacial soil development (e.g. Bibus et al. 1996; Terhorst 2007), whereas in other regions at least two soils have been attributed to the same period (e.g. Marković et al. 2006). In this context, it should be noted that MIS 7 is, in contrast to other "warm" isotope stages (e.g. MIS 5 or 9), characterised by three pronounced stages of low global ice volume that reach a level similar to the situation of the Holocene (Fig. 12). Periods of low global ice volume are likely to represent pronounced interstadial or even interglacial conditions on the continents. This assumption has been proven for marine pollen sequences (e.g., Desprat et al.2006), long and continuous lacustrine vegetation records (cf. Tzedakis et al. 1997, 2001) as well as speleothems (Holzkämper et al. 2005) from all over Europe. Probably the best examples for the partition of MIS 7 are the long pollen records from the French Massif Central, some $300 \mathrm{~km} \mathrm{SW}$ of Sierentz. There, three warm phases attributed to MIS 7 (Bouchet Interstade 1-3) with deciduous forest (with Quercus, Corylus, Fagus, Carpinus) are separated by periods with treeless vegetation (Belvezet and Bonnefond stade). These cold episodes are characterised by open grassland vegetation with Artemisia and Poaceae (Reille et al. 1998). While during periods of woodland vegetation strong soil formation has to be expected at times (i.e. luvisols), reduced vegetation cover during colder periods probably induced reworking of sediment. By the example of the Meikirch complex, it has been shown that three warm periods with interglacial-like vegetation occurred during MIS 7 also in the Alpine foreland (Preusser et al. 2005). It is furthermore interesting to note that the Meikirch complex was preceded and followed by glaciation of the Aare Valley, i.e. during MIS 8 and 6. According to this evidence, important ice advances from the Alps into the foreland have to be expected for these two time periods. Evidence for a major glaciation of the Swiss Alps during MIS 6 reaching far into the Jura Mountains has also been provided by cosmogenic nuclide dating of erratic boulders (Graf et al. 2007). Furthermore, Preusser and Fiebig (2009) observed major loess accumulation during MIS 6 and MIS 8 in NE Austria, implying important ice advances at times. Hence, there appear to be much more glaciations of the Alps than expected by Penck \& Brückner (1909), as already indicated by Schlüchter \& Kelly (2000). Any such period, i.e. probably any even marine isotope stage prior of the Middle Pleistocene, is a potential candidate for the formation of the High Terrace at Sierentz.

The complexity of the cover sediments together with the results of IRSL dating strongly suggests that the High Terrace of Sierentz is older than MIS 7 (>250 ka), implying at first a correlation with MIS 8 (ca. $260 \mathrm{ka}$ ). However, soil development on top of the High Terrace U9 is very strong with a distinct petrocalcic horizon. In another outcrop within the same terrace formation at Blotzheim, some $4 \mathrm{~km}$ to the south-east of Sierentz, decalcification reaches $>3 \mathrm{~m}$ into the gravel. On the Lower Terrace, pedogenesis (luvisol) reaches a depth of not more than $1 \mathrm{~m}$ with only weakly and locally developed calcic horizons in the gravel (Rentzel 1997). This indicates that pedogenesis on top of the gravel U9 was much more pronounced than during the Late Glacial/Holocene and a resultant possible interpretation is that the soil reflects pronounced interglacial conditions prior to MIS 7.

However, Desprat et al. (2006) concluded from their offshore pollen record, that, firstly, an interstadial similar to the Late Glacial occurred during the latest part of MIS 8 and, secondly, that MIS 7.5 was a pronounced and rather humid period that lasted some 8000 yrs. If humidity was more pronounced than during the Holocene this could explain a more intense

398 P. Rentzel et al. 
pedogenesis at times. Hence, soil development on top of the High Terrace could possibly also be correlated with MIS 7.5. A cold period following pedogenesis on top of the High Terrace is reflected by the soliflucted sediments U9a but no evidence for cryoturbation has been found; this probably reflects a not too pronounced cold phase such as MIS 7.4.

If a correlation of the soil on top of the gravel with MIS 7.5 is correct, a subsequent question is how to correlate the chernozem (U4) on top of the soil sequence. It would likely be an equivalent of MIS 7.1 in case the lower soil horizons correlate with MIS 7.3 (U6), MIS 7.5 (U8) and MIS 9 (U9b), but this is in apparent conflict with the interpretation discussed above. Nevertheless, it is important to note that soil U4 is less well developed compared to the soils from the lower part of the sequence. Interestingly, Desprat et al. (2006) identified in their pollen record a period of open temperate forest development following the full warm period (interglacial conditions) of MIS 7.1. Hence, it appears possible to include all periods of soil development observed at Sierentz into MIS 7. As a consequence, the minimum age of the High Terrace should be considered as MIS 8 (ca. $260 \mathrm{ka}$ ) but the strong soil development on top of the gravel could alternatively points toward a minimum age of MIS 10 (ca. $350 \mathrm{ka})$.

\section{Conclusions}

The Sierentz section reflects a complex sequence covering the classical High Terrace sensu Penck \& Brückner (1901/09), for which usually a correlation with MIS 6 (ca. $150 \mathrm{ka}$ ) has been assumed. However, the succession on top of the gravel is characterised by several phases of soil formation as well as erosional episodes under periglacial conditions. Interpretation of the pedological horizons together with the results of IRSL dating imply that the lower part of the cover sediments was formed during MIS 7. Not finally solved is the age of pedogenesis on top of the fluvio-glacial gravel sheet (High Terrace) that may correspond to the earliest MIS 7 (ca. $250 \mathrm{ka}$ ) or MIS 9 (ca. $320 \mathrm{ka}$ ). As a consequence, the minimum age of gravel deposition appears to be either MIS 8 (ca. $260 \mathrm{ka}$ ) or MIS 10 (ca.350 ka).

Recent dating evidences from regions such as Bavaria (Fiebig \& Preusser 2003; Link \& Preusser 2006), the Aare Valley (Preusser et al. 2005, 2007; Preusser \& Schlüchter 2004), the Jura Mountains (Graf et al.2007, Braillard \& Guélat 2008), the Lake Zürich area (Preusser et al. 2003) and NE Austria (Preusser \& Fiebig 2009) indicate a much more complex history of Pleistocene glaciations than is assumed in the classical Penck \& Brückner (1901/09) scheme. From this evidence it appears likely that all cold phases during the Middle/Late Pleistocene (MIS 2, 4, 5b, 5d, 6, 8, 10), which have been identified in both marine isotope as well as continental pollen records, were characterised by major glaciations of the Alps and the formation of gravel terraces in the foreland. The apparent subdivision of the Pleistocene into four major glaciations that has earlier been observed in many areas hence does apparently not reflect the full glacial history of the Alps. Actually, several local terrace stratigraphies have been modified to include sublevels of terraces implying that the established scheme is more complex than previously assumed (cf. Becker-Haumann 2001; Boenigk $\&$ Frechen 2006). The present study from Sierentz can be considered a further example of the complexity of terrace formation during the Quaternary.

\section{Acknowledgements}

We thank Thomas Hauck, Dorota Wojtczak, Luca Abbühl, Beatrix Ritter, Kristin Ismail-Meyer, Denis Aubry and Michel Guélat for their help during fieldwork. Norbert Spichtig und Udo Schön assisted with the equalization of digital photographs and Guido Lassau provided access to the infrastructre of Archäologische Bodenforschung Basel-Stadt. Brigitte Van Vliet-Lanoë provided references on periglacial features and Stephane Kock is thanked for details with regard to tectonics. We also thank Christian Jeunesse, Service Régional de l'Archéologie, Bénédicte Viroulet, Service Départemental de l'Archéologie du Haut-Rhin, Jean-Marie Belliard, major of Sierentz, Hugues Hecklen (promoteur "Foncière Hugues Aurèle"), Aimé Brun (Geometer) and Conseil Général du Haut-Rhin for financial support. The authors are also grateful to V. Pümpin, M. Stäuble, L. Braillard for comments on earlier drafts of the manuscript and we thank P. Antoine and B. Nivière for their constructive reviews of the paper.

\section{REFERENCES}

Aitken, M.J. 1998: An introduction to optical dating. 267 pp., University Press, Oxford.

Antoine, P., Rousseau, D.-D., Zöller, L., Lang., A., Munaut, A.-V., Hatté, C. \& Fontugne, M., 2001: High-resolution record of the last Interglacial-glacial cycle in the Nussloch loess-palaeosol sequences, Upper Rhine Area, Germany. Quaternary International 76/77, 211-229.

Antoine, P., Limondin Lozouet, N., Chaussé, C., Lautridou, J.-P., Pastre, J.-F., Auguste, P., Bahain, J.J., Falguéres, C. \& Galehb, B., 2007: Pleistocene fluvial terraces from northern France (Seine, Yonne, Somme): synthesis, and new results from interglacial deposits. Quaternary Science Reviews $26,2701-2723$.

Anselmetti, F.S., Drescher-Schneider, R., Furrer, H., Graf, H.R., Lowick, S., Preusser, F. \& Riedi, M.A. (submitted): A 200'000 years sedimentation history of a perialpine overdeepened glacial valley (Wehntal, N-Switzerland). Swiss Journal of Geosciences.

Adhoc AG Boden 2005: Bodenkundliche Kartieranleitung. Hannover, 438 p.

Bassinot, F.C., Labeyrie, L.D., Vincent, E., Quidelleur, X., Shackleton, N.J. \& Lancelot, Y. 1994: The astronomical theory of climate and the age of the Brunhes-Matuyama magnetic reversal. Earth and Planetary Science Letters 126, 91-108.

Becker-Haummann, R. 2001: The depositional history of the Bavarian Allgäu area at the turn of the Tertiary/Quaternary, Northern Alpine Foreland, Germany - a set of paleogeological maps. Quaternary International 79, $55-64$.

Beckmann, Th. 1991: Mikromorphologische Untersuchungen am Lössprofil der Ziegeleigrube Allschwil (Basel-Landschaft). Freiburger Geographische Hefte 33, 47-53.

Bibus, E. 1990: Das Mindestalter des "Jüngeren Deckenschotters" des Rheins bei Basel aufgrund seiner Deckschichten in der Ziegelei Allschwil. Jahrbuch des geologischen Landesamtes Baden-Württemberg 14, 223-234.

Bibus, E. 1995: Äolische Deckschichten, Paläoböden und Mindestalter der Terrassen in der Iller-Lech-Platte. Geologica Bavarica 99, 135-164.

Bibus, E., Bludau, W., Bross, C. \& Rähle,W. 1996: Der Altwürm- und Rissabschnitt im Profil Mainz-Weisenau und die Eigenschaften der Mosbacher Humuszonen. Frankfurter Geowissenschaftliche Arbeiten D20, 21-52.

Boenigk, W. \& Frechen, M. 2001: The loess record in sections at Koblenz-Metternich and Tonchesberg in the Middle Rhine Area. Quaternary International 76, 201-209. 
Boenigk, W. \& Frechen, M., 2006: The Pliocene and Quaternary fluvial archives of the Rhine system. Quaternary Science Reviews 25, 550-574.

Braillard, L. \& Guélat, M. 2008: Une nappe alluviale étagée du Pléistocène supérieur dans la vallée de Delémont (Jura suisse): lithostratigraphie et datation. Quaternaire 19,217-228.

Brochier, J.-L. \& Joos, M. 1982: Un élément important du cadre de vie des Néolithiques d'Auvernier Port: le lac. Approche sédimentologique. In: La station néolithique d'Auvernier-Port. Cadre et évolution (Ed. by Billanboz et al.) Cahier d'Archéologie Romande 25, Lausanne, 43-67.

Bullock, P., Federoff, N., Jongerius, A., Stoops, G. \& Tursina, T. 1985: Handbook for soil thin section description. 152 p., Waine Research Publishers, Wolverhampton.

Cordier, S., Harmand, D., Frechen, M. \& Beiner, M. 2006: Fluvial system response to Middle and Upper Pleistocene climate change in the Meurthe and Moselle valleys (Eastern Paris Basin and Rhenish Massif). Quaternary Science Reviews 25, 1460-1474.

Courty, M.-A., Goldberg, P. \& Macphail, R. 1989: Soils and micromorphology in archaeology. 344 p., Cambridge University Press.

Desprat, S., Sánchez Goñi, M.F., Turon, J.L., Duprat, J., Malaiźe, B. \& Peypouquet, J.P. 2006: Climatic variability of Marine Isotope Stage 7: direct landsea-ice correlation from a multiproxy analysis of a north-western Iberian margin deep-sea core. Quaternary Science Reviews 25, 1010-1026.

Fao-Unesco 1997. Colour chart of the 106 soil units of the FAO-UNESCO Soil Map of the World Legend. Elsevier Science Publishers, Amsterdam.

Fiebig, M. \& Preusser, F. 2003: Das Alter fluvialer Ablagerungen aus der Region Ingolstadt (Bayern) und ihre Bedeutung für die Eiszeitenchronologie des Alpenvorlandes. Zeitschrift für Geomorphologie - Neue Folge 47, 449-467.

Fiebig, M. \& Preusser, F. 2007: Investigating the amount of zeroing in modern sediments of River Danube, Austria. Quaternary Geochronology 2, 143-149.

Fischer, H., Hauber, L. \& Wittmann, O. 1971: Geologischer Atlas der Schweiz 1:25’000, Blatt 1047: Basel. Erläuterungen der Schweizerischen Geologischen Kommission. 55 p., Bern.

Frechen, M. 1999: Upper Pleistocene loess stratigraphy in Southern Germany. Quaternary Science Reviews 19, 243-269.

Frechen, M., Zander, A., Cílek, V. \& Ložek, V. 1999: Loess chronology of the Last Interglacial/Glacial cycle in Bohemia and Moravia, Czech Republic. Quaternary Science Reviews 18, 1467-1493.

Frechen, M., Oches, E.A. \& Kohfeld, K.E. 2003: Loess in Europe - mass accumulation rates during the Last Glacial Period. Quaternary Science Reviews $22,1835-1857$.

Fuchs, M. \& Lang. A. 2009: Luminescence dating of hillslope deposits - A review. Geomorphology 109, 17-26.

Giamboni, M., Wetzel, A., Nivière, B. \& Schumacher, M. 2004: Plio-Pleistocene folding in the southern Rhine graben recorded by the evolution of the drainage network (Sundgau area, northwstern Switzerland and France). Elogae Geologicae Helvetiae 97, 17-31.

Graf, A., Strasky, S., Ivy-Ochs, S., Akcar, N., Kubik, P.W., Burkhardt, M. \& Schlüchter, Ch. 2007: First results of cosmogenic dated pre-Last Glaciation erratics from the Montoz Area, Jura Mountains, Switzerland. Quaternary International 164/165, 43-52.

Guélat, M. 2000: Approche micromorphologique. In: Aubry, D., Guélat, M., Detrey, J., In: Dernier cycle glaciaire et occupations paléolithiques à Alle, Noir Bois (Jura, Suisse) (Ed. by Othnin-Girard, B. et al.). Cahier d'archéologie jurassienne, 10. Office du patrimoine historique et Société jurassienne d'Emulation, Porrentruy, Delémont, 61-80.

Hadjouis, A. 1987: Granulométrie des fractions sableueses. In: Miskovsky, J.C. (ed.), Géologie de la Préhistoire. Paris, géopré, 413-426.

Häuselmann, P., Fiebig, M. \& Kubik, P.W.2007: A first attempt to date the original "Deckenschotter" of Penck \& Brückner with cosmogenic nuclides. Quaternary International 164/165, 33-42.

Holzkämper, S., Spötl, C. \& Mangini, A. 2005: High-precision constraints on timing of Alpine warm periods during the middle to late Pleistocene using speleothem growth periods. Earth and Planetary Science Letters 236, 751-764.

Jagher, R., Rentzel,Ph. \& Schwarz,P-A. 2003: Ein altsteinzeitliches Geröllartefakt aus Riehen - Ergebnisse der archäologischen und naturwissenschaft- lichen Untersuchungen (with contributions by A. Hilgers \& U. Radtke). Jahresbeicht der Archäologischen Bodenforschung Basel-Stadt 2001, 103-128, Basel.

Kulig, G. 2005: Erstellung einer Auswertesoftware zur Altersbestimmung mittels Lumineszenzverfahren unter spezieller Berücksichtigung des Einflusses radioaktiver Ungleichgewichte in der 238U-Zerfallsreihe. Unpublished BSc thesis, Technical University Bergakademie Freiberg.

Kock, S., Kramers, J.D., Preusser, F. \& Wetzel, A. 2009a: Comparison of U/Th and optical dating of Late Pleistocene terraces deposits from the Hochrhein area (N Switzerland, SW Germany). Quaternary Geochronology Geochronology 4, 363-373.

Kock, S., Huggenberger, P., Preusser, F., Rentzel, Ph. \& Wetzel, A. 2009b: Formation and evolution of the Lower Terrace of the Rhine River in the area of Basel. Swiss Journal of Geosciences 102, 307-321.

Munsell Color Co. 1992: Munsell Soil Color Charts. Revised edition. Newburgh, New York, USA.

Laubscher, H. 2001: Plate interactions at the southern end of the Rhine graben. Tectonophysics 343: 1-19.

Li, S.-H. 1991: Removal of the thermally unstable signal in optical dating of K-feldspar. Ancient TL 9, 26-29.

Li, S.-H. 1994: Optical dating: Insufficiently bleached sediments. Radiation Measurements 23, 563-567.

Link, A. \& Preusser, F. 2006: Hinweise auf eine Vergletscherung des Kemptener Beckens während des Mittelwürms. Eiszeitalter \& Gegenwart 55, $65-88$.

Lund, S., Stoner, J.S., Channell, J.E.T. \& Acton, G. 2006: A summary of Brunhes paleomagnetic field variability recorded in Ocean Drilling Program cores. Physics of the Earth and Planetary Interriors 156, 194-204.

Miara, S., Zöller, L., Rögner, K. \& Rousseau, D.-D. 1996: Quartäraufschlüsse bei Baltringen/Riss und Gliederung des Riss-Komplexes - neue stratigraphischen, pedologische und geochronologische Aspekte. Zeitschrift für Geomorphologie N.F. 40, 209-226.

Nivière, B., Giamboni, M., Innocent, C. \& Winter, T. 2006: Kinematic evolution of a tectonic wdge above a flat-lying decollement: the Alpine foreland at the interface between Jura Mountains (N Alps) and south of the Upper Rhine Graben. Geology 34, 469-472.

Nivière, B. \& Marquis, G. 2000: Evolution of terrace risers along the Upper Rhine Graben inferred from morphologic dating methods: evidence of climatic and tectonic forcing. Geophyscs Journal International 141, 577 594.

Nivière, B. \& Winter, T. 2000: Northwards fold propagation of the Jura within the souther Upper Rhine Graben. Seismotectonic consequences. Global and Planetary Change 27, 263-288.

Penck, A. \& Brückner E. 1901/09: Die Alpen im Eiszeitalter. Tauchnitz (Leipzig): $1157 \mathrm{pp}$.

Preusser, F. 1999: Lumineszenzdatierung fluviatiler Sedimente - Fallbeispiele aus der Schweiz und Norddeutschland. Kölner Forum für Geologie und Paläontologie 3, $63 \mathrm{p}$.

Preusser, F. 2003: IRSL dating of K-rich feldspars using the SAR protocol: Comparison with independent age control. Ancient TL 21, 17-23.

Preusser, F. \& Kasper, H.U., 2001: Comparison of dose rate determination using high-resolution gamma spectrometry and inductively coupled plasma - mass spectrometry. Ancient TL 19, 17-21.

Preusser, F., Geyh, M.A. \& Schlüchter, Ch. 2003: Timing of Late Pleistocene climate change in lowland Switzerland. Quaternary Science Reviews 22, $1435-1445$.

Preusser, F. 2004a: Lumineszenzdatierung von Sedimenten als Beitrag zur Rekonstruktion der pleistozänen Klimageschichte des Alpenraums. Zeitschrift für Gletscherkunde und Glazialgeologie 38, 95-116.

Preusser, F. 2004b: Towards a chronology of the Upper Pleistocene in the Northern Alpine Foreland. Boreas 33, 195-210.

Preusser, F. \& Schlüchter, Ch. 2004: Dates from an important early Late Pleistocene ice advance in the Aare Valley, Switzerland. Eclogae Geologicae Helvetiae 97, 245-253.

Preusser,F., Drescher-Schneider, R., Fiebig, M. \& Schlüchter, C. 2005: Reinterpretation of the Meikirch Pollen record, Swiss Alpine Foreland, and its implication for middle pleistocene chronostratigraphy, Journal of Quaternary Science 20,607-620.

400 P. Rentzel et al. 
Preusser, F., Blei, A., Graf, H.R. \& Schlüchter, Ch. 2007: Luminescence dating of Würmian (Weichselian) proglacial sediments from Switzerland: methodological aspects and stratigraphical conclusions. Boreas 36, 130-142.

Preusser, F., Degering, D., Fuchs, M., Hilgers, A., Kadereit, A., Klasen, N., Krbetschek, M., Richter, D. \& Spencer, J. 2008: Luminescence dating: Basics, methods and applications. Eiszeitalter \& Gegenwart (Quaternary Science Journal) 57, 95-149.

Preusser, F.,Fiebig, M. 2009:European Middle Pleistocene loess chronostratigraphy: Some considerations based on evidence from the Wels site, Austria. Quaternary International 198,37-45.

Rentzel, Ph. 1997: Geologisch-bodenkundliche Untersuchungen an den Niederterrassenfeldern bei Basel unter besonderer Berücksichtigung der spätlatènezeitlichen Fundstelle Basel-Gasfabrik". Jahresbericht der Archäologischen Bodenforschung Basel-Stadt 1994, 31-52.

Rentzel, Ph., Sedlmeier, J., Steppan, K. \& Wick, L. 1999: Die spätglaziale Karstspaltenfüllung im Schachletetal bei Dittingen BL. Archäologie der Schweiz, 22, 1999/1, 8-12.

Rivère, A. 1977: Méthodes granulométriques. Techniques et interprétations. Collection techniques et méthodes sédimentologiques. Paris, Masson.

Rousseau, D.D., Zöller, L. \& Valet, J.P. 1998: Late Pleistocene climatic variations at Achenheim, France, based on a magnetic susceptibility and TL chronology of loess. Quaternary Research 49, 255-263.

Schlüchter, C. \& Kelly, M. 2000: Das Eiszeitalter in der Schweiz. Publ. IGCP378, Geologisches Institut der Universität Bern.

Sissingh, W. 1998: Comparative Tertiary stratigraphy of the Rhine Graben, Bresse Graben and Molasse Basin: correlation of Alpine foreland events. Tectonophysics 300: 249-284.

Théobald, N. 1958: Altkirch - Huningue. Carte géologique de la France à 1/50'000; 445. Service de la Carte Géologique de la France. Paris, 37-21.

Therhorst, B., Frechen, M. \& Reitner, J. 2002: Chronostratigraphische Ergebnisse aus Lössprofilen der Inn- und Traun-Hochterrassen in Oberösterreich. Zeitschrift für Geomorphologie N.F. Supplement Band 127, 213232.

Tzedakis, P.C., Andrieu, V., Beaulieu, J.-L. de, Crowhurst, S., Follieri, M., Hooghiemstra, H., Magri, D., Reille, M., Sadori, L., Shackelton, N.J. \& Wijmstra, T.A. 1997: Comparison of terrestrial and marine records of changing climate of the last 500'000 years. Earth and Planetary Science Letters 150,171-176.
Tzedakis, P.C., Andrieu, V., Beaulieu, J.-L. de, Birks, H.J.B., Crowhurst, S., Follieri, M., Hooghiemstra, H., Magri, D., Reille, M., Sadori, L., Shackelton, N.J. \& Wijmstra, T.A. 2001: Establishing a terrestrial chronological framework as a basis for biostratigraphical comparisons. Quaternary Science Reviews 20,1583-1592.

Ustaszewski, K. \& Schmid, S.M. 2007: Latest Pliocene to recent thick-skinned tectonics at the Upper Rhine Graben - Jura Mountains junction. Swiss Journal of Geosciences 100, 293-312.

Van Husen, D. 2004: Quaternary glaciations in Austria. In Ehlers, J. \& Gibbard, P. (eds.): Quaternary Glaciations - Extent and Chronology. Elservier, Amsterdam.

Van Vliet-Lanoë, B. 1987: Le rôle de la glace de ségrégation dans les formations superficielles de l'Europe du Nord-Ouest. Thèse de Doctorat d'Etat, Université Paris I, Gand, Bélgique, 864 pp.

Van Vliet-Lanoë, B., Magyari, A. \& Meilliez, F. 2004: Distinguishing between tectonic and periglacial deformations of quternary continental deposits in Europe. Global and Planetary Change 43,103-127.

Wallinga, J. 2002: Optically stimulated luminescence dating of fluvial sediments: a review. Boreas 31,303-322.

Wittmann, O. 1961: Die Niederterrassenfelder im Umkreis von Basel und ihre kartographische Darstellung. Basler Beiträge zur Geographie und Ethnologie, 3 .

Wittmann, O., Hauber, L., Fischer, H., Rieser, A. \& Staehelin, P. 1970: Geologischer Atlas der Schweiz, 1:25'000, Blatt 1047 Basel.

WRB 2007: IUSS working group WRB, World Reference Base for Soil Ressources 2006, first update 2007. World Soil Ressources Reports No. 103. FAO Rome.Ziegler, P.A. 1994: Cenozoic rift system of western and central Europe: an overview. Geologie en Mijnbouw 73, 99-127.

Zollinger, G. 1991: Zur Landschaftsgenese und Quartärstratigraphie am südlichen Oberrhein - am Beispiel der Lössdeckschichten der Ziegelei in Allschwil (Kanton Basel-Landschaft). Eclogae geologicae Helveticae 84, 739-752.

Manuscript received May 9, 2008

Revision accepted September 22, 2009

Published Online first December 9, 2009

Editorial Handling: A. Wetzel \& S. Bucher 